\title{
BOTHO/UBUNTU: THE HEART OF AFRICAN ETHICS
}

\author{
Ramathate Dolamo \\ Department of Philosophy, Practical and Systematic Theology \\ University of South Africa
}

\begin{abstract}
The tenets of botho/ubuntu analysed in this article demonstrate the interplay between individuals and their respective communities. A thorough but not exhaustive definition and description of ubuntu are given, indicating its indispensable elements, which are derived from African culture and religion. This article indicates that culture and religion are not static entities, that in this postmodernist and globalising world ubuntu could be enriched by taking cognisance of the values and principles of other cultures and religions.
\end{abstract}

Key Words: Botho/Ubuntu; Culture; Religion; Communalism; Individualism; Ethics

\section{Introduction}

Post-colonial Africa needs to recapture the values and principles enshrined in the philosophy of botho/ubuntu if its people are to enjoy the dignity that they deserve. Not all was lost over the past 500 years of slavery, colonisation and globalisation. The secret is for individuals to realise that they would become human only by becoming members of their respective communities. As Shutte (2001:30) correctly argues:

Our deepest moral obligation is to become more fully human and this means entering more and more deeply into community with others. So although the goal is personal fulfilment, selfishness is excluded.

Although the concept of botho/ubuntu is as old as humanity itself, and by no means confined to Africa only, the popularity of the notion as such was brought into sharper focus as postindependent African states started to reflect on their historical past, colonisation and the prospects for nation-building, as well as the creation of prosperity. Botho/Ubuntu is therefore an integral part of African ethics that is steeped in issues of liberation, development, identity, etc. It has to do with a person's integrity and dignity. The tenets of botho/ubuntu are being revisited as Africa is searching for ethical principles and values that can assist in the designing of models of development and wealth creation within the neoliberal and globalising framework. Methodologically this article, firstly, defines and describes the concept of botho/ubuntu; secondly, it discusses the forces that undermined the precepts of botho/ubuntu as the continent came into contact with other cultures and religions; and thirdly, and most importantly, it suggests ways and means by which those lost or distorted liberating principles and values embedded in botho/ubuntu could be retrieved for the benefit of Africa and Africans.

\section{Definition of Botho/Ubuntu}

Botho in the Sesotho languages, that is Sepedi, Setswana and (Southern) Sesotho, or ubuntu in the Nguni languages, that is isiZulu, isiXhosa, isiNdebele and isiSwati, is a South African 
way of expressing a way of living that is universal (Shutte 2001:2; Broodryk 2008:62). The other two South African black languages, that is, Xhitsonga and Tshivenda, also have derivatives of the term. Many societies and communities that are still living in accordance with traditional values and principles adhere to the dictates of botho/ubuntu. The industrial revolution, urbanisation and modernisation in general have led to the erosion of some of the values and norms of ubuntu. There is a general complaint internationally about this malaise. In Korea, for example, they complain about the erosion of sansaeing (conviviality) and in the Philippines the youth are accused of ignoring kapwa-tao, which in Tagalog means "as human beings we must respect one another because we need one another". Even in the West people are starting to hanker after those good old days when neighbours, relatives and friends would rally around one another in times of happiness and sadness.

But what does botho or ubuntu stand for?

To some botho/ubuntu means 'humanity' (Shutte 2001:2), while to others it means 'humanness' (Broodryk 2008:41). Explaining botho/ubuntu as humanity may be rather misleading and confusing, since humanity may simply refer to humankind. Humanness seems to be more appropriate as it refers to the inner core of an individual. It has to do with the soul of the person. Shutte (2001:2) elaborates on his definition of botho/ubuntu thus:

The concept of UBUNTU embodies an understanding of what it is to be human and what is necessary for human beings to grow and find fulfilment. It is an ethical concept and expresses a vision of what is valuable and worthwhile in life. This vision is rooted in the history of Africa and it is at the centre of the culture of most South Africans.

Botho/Ubuntu is the ideal of being human, derived from a worldview based on the guiding principle of "umuntu ngumuntu ngabantu" (I am a person through other persons) (Brooddryk 2008:41). In Sesotho it is rendered as "motho ke motho ka batho ba bangwe". What goes into making a human being fully and authentically human, or what goes into constituting somebody's humanness is huge. Broodryk (2008:63-69) mentions a few of the core values, namely compassion, helpfulness, forgiveness, understanding, etc. Ng'weshemi (2002:23) adds to this list characteristics such as wisdom, hard work, fidelity, humility and godliness. Broodryk (2008:17) says "Ubuntu is a comprehensive ancient African world-view based on the values of intense humanness, caring, sharing, respect, compassion and associated values, ensuring a happy and qualitative community life in the spirit of family". In fact, Broodryk (2008:45) goes so far as to give us the social origins of ubuntu. According to him, the notion of botho/ubuntu started in Egypt as far back as 1500 BCE. He indicates that seven cardinal values in the Netchar Maat culture were truth, justice, propriety, harmony, balance, reciprocity and order. These were the bases and guidelines for correct and moral behaviour. Most of these values and beliefs were transferred to other parts of Africa during the cultural movement to the southern parts of the continent. The iron-making people of Central and Eastern Africa migrated to the south and settled in present-day Limpopo and Mpumalanga about 1050 years ago, while a new culture known as Leopards Kopje settled at Mapungubwe. By the 1600s various Iron Age settlements had been established throughout what are now the Gauteng Province and Highveld areas.

Ubuntu is therefore at the core of human existence. "This inner being is understood to be the center of human personalities, feelings, thoughts and will" (Mafunisa in Nicholson 2008:116). 


\section{Culture and Religion}

Culture and religion are the two main pillars of botho/ubuntu in Africa. Whether culture produces religion or religion produces culture will remain a 'chicken-or-egg' question. But what has become clear is that botho/ubuntu cannot have emerged in a religious or cultural vacuum. Mol (1976), for example, when sketching a new social-scientific theory of religion argues that the role of religion in society is to sacralise its culture and civilisation. Berger and Berger (1976) argue along the same lines when they describe the role of religion as that of lending legitimacy to culture. Berger and Berger (1976:29) put it as follows:

Through most of human history, the principal legitimations for the maintenance of society have been provided by religion. The mechanism by which such religious legitimation operates is essentially simple. The structures and institutions of society are interpreted as being part and parcel of the basic order of the universe. In this way, the routines of social experience are linked directly to the very nature of things as willed by the gods.

African religious scholars will always point out that Africans are generally or notoriously religious. As Mafunisa (in Nicholson 2008:120) says:

African traditional religion is a way of life and a search for well-being within the community in the here and now of everyday experience. It encompasses beliefs concerning a supreme being, ancestors and the mediation of diviners and/or rainmakers.

Ng'weshemi (2002:10) puts this more forcefully when he states:

For Africans all life is religious. Religion infiltrates through every dimension of people's life and experience to the extent that separation between the sacred and the secular, the visible and the invisible, or the spiritual from the material, is impossible (Cf. Ng'weshemi 2002:14; Shutte 2001:203).

And Bujo (2003:123) emphasises that, "as Africans see it, it is impossible to define the human person in purely secular or purely religious terms, since he is both at once. Where one of these dimensions is lacking, one can no longer speak of human person qua human person."

Be that as it may, the concern of Chitando (in Nicholson 2008:46) should be heeded when he argues that another path is possible, "where certain ethical principles are seen as derived from religion, without having to subsume all ethics under religion". This perspective could be useful where religion or culture or both might be misused to legitimise oppressive decisions and actions. Indeed, religion and ethics may be conjoined, but should be regarded as two autonomous fields.

\section{Description of Botho/Ubuntu}

\section{'Ubuntu' as a Process}

Although every individual is born human, the formation of humanness comes through the process of socialisation. Bujo (2003:14) puts this succinctly:

It must be recalled that African ethics does not define the person as self-realisation or as ontological act; rather, it describes a person as a process of coming into existence in the reciprocal relatedness of individual and community, where the latter includes not only the deceased but also God. 
In this regard Ng'weshemi (2002:15) says: "for Africans, one is not human simply by birth. Rather one becomes human through a progressive process of integration into society" Therefore one cannot speak of botho/ubuntu outside of community. "This means that the human person in Africa is from the very beginning in a network of relationships that constitute his inalienable dignity" (Bujo 2003:117). Bujo (2003:117) adds that even the embryo and foetus are already a person, surrounded by the loving relations of the dead and living. So whether at birth/conception and death, Africans are always in community. The dying also teach the living to face death when their time comes (cf. Shutte 2001:23; Mcunu 2004:8). Ubuntu as a process towards achieving humanness takes an individual through various stages of development.

Mcunu (2004) made an interesting study of the concept of the dignity of the human person. Human dignity, according to him, includes values such as respect, freedom and free will; he indicates that dignity is something intrinsic and rooted in personhood itself, regardless of a person's social standing in the community.

According to him:

Dignity entails two aspects, namely an intrinsic and extrinsic aspect. Dignity is intrinsic in the sense that it is from within, for example, self-possession and self-directing. It is intrinsic in the sense that there have to be dignified conditions for people to live a dignified life (Mcunu 2002:4).

He elaborates by saying that human dignity is both vertical and horizontal, that is, human with other humans and creation, and humans with God. Human dignity cannot be dichotomised into mind and body, or spiritual and physical. He accuses materialistic anthropology for focusing on material nature and ignoring mental, emotional and spiritual nature. Behavioural anthropology is equally criticised for asserting that since behaviour is observable and not the person's mind, human activity is solely determined by his/her social environment.

The African view is holistic in its approach towards the human person. The African view does not compartmentalize the human person but situates his/her wellbeing within a web of relationships and the source of the web is in the Supreme Being... Whatever is placed out of balance in the human person causes spiritual, physical and mental disease (Mcunu 2004:8).

One other aspect of human dignity that is critical in discussions of botho/ubuntu is human integrity: it may be conferred externally, but is developed internally. The botho/ubuntu that one exudes and shares with others is reciprocated by the botho/ubuntu that one receives from others. It is true that dignity is inherently possessed by all humans, but it can be enhanced or diminished according to what the individual does or does not do within the community. Using the human rights language, one's dignity and integrity could be superficial or deep according to the extent to which one recognises the rights of others by discharging one's obligations and responsibilities to the other. Human rights are subject to human duties, as it were. "If there are any rights, which the individual deserves, they are seen as secondary to the exercise of their duties" (Ng'weshemi 2002:18).

Although the nature, objectives and development of human rights is not the focus of this article, it is necessary to mention that the culture of human rights has evolved over many centuries prompted by the different circumstances and needs of the time and place. Historical events such as the American War of Independence, also known as the American Revolution (1775-1783) and the French Revolution (1789-1799) helped to forge the culture of human 
rights. The Universal Declaration of Human Rights (1948), the African Charter on Human Rights and People's Rights (1986) are some of the instruments that were developed to facilitate the culture of human rights in which rights, responsibilities, roles and privileges of parties involved were spelt out. Post-independence African nations also developed their own respective constitutions and bills of rights. One major criticism against all these bills of rights is that individuals and not communities are the point of departure. That is, the thrust of these instruments is individualistic and not communal, an attitude which obviously goes against the principles and values of botho/ubuntu (Mcunu 2004:56-58).

There are five main assumptions that make up the African religious view: (a) God is the creator and sustainer of life; (b) there are spirit beings such as those in nature, superhuman beings and founders of clans; (c) there are spirits of long-departed humans; (d) there are animal and plant sprits; and (e) there are spirits of objects without biological life (Ng'weshemi:2002:10; Mbiti:1991:68-69; Mbiti:1970:220-243). The universe is therefore, according to Ng'weshemi (2002:11): "likened to a spider web in which the human beings are at the centre of God's creation, and all other creatures are also connected in a system of relationships which interact with one another".

Within a community an individual is nurtured into becoming a mature and responsible human being who would embrace the values, norms and principles of botho/ubuntu. The rites of passage are the key in imparting the philosophy of botho/ubuntu. From conception to birth to puberty and even until death, an individual is nurtured and socialised, because life and death are inter-linked. Death introduces an individual into the world of the living dead (Mbiti 1970; Setiloane 1989; Magesa 2002; Ng'weshemi 2002; Mcunu 2004). As Ng'weshemi (2002:31) says: “As a climax of one's existence in the visible world, death is a passage into the unseen yet not desolate spiritual world, where life continues through contact with the living". Ancestors also are part of the extended family. Birth introduces a person into this earthly life and death does not discontinue this relationship. The dead continue to influence life on earth beyond the grave; God is seen as the centre of the earth and when one dies, one moves closer to the centre of the earth, God (Shutte 2001:29).

For botho/ubuntu to succeed, a delicate balance in the cosmos, both in the universe and in the spiritual realm, needs to be maintained. This is what Mkhize (in Nicholson 2008:35-44) emphasises when writing about botho/ubuntu and harmony in African ethics. He says that botho/ubuntu is about creating harmonious relationships in a community, with God as the source and origin of morality. He says, "the idea of life force ... is predicated upon the notion of consubstantiation ... The notion of being in harmony with one another and the universe ... is best explained through the principle of cosmic unity, and human wrong doing, unethical conduct or social injustice destabilises this order" (2008:38-39).

\section{Erosion of 'botho/ubuntu'}

After the arrival of colonists, traders and missionaries in Africa the sense of botho/ubuntu or African humanness became altered and distorted. The phenomenon was a double-edged sword. One edge held possibilities for Africa's advancement in science and technology, whilst the other caused long-lasting effects on the self-understanding of the African people. As Ng'weshemi (2002:39) comments:

The work of the agents and agencies of the West have in various ways caused an experience of disorientation and distortion of the identity, dignity, humanness, and value 
of African people's life. The encounter has plunged African people into an existential diversion and dehumanization.

People who came to Africa as colonisers, missionaries and researchers regarded Africans as primitive, backward, irrational, ignorant, pagan and uncivilised, and their mission was to correct all that using any means possible, including murder, pillage, plunder and theft. Missionaries immersed in $17^{\text {th }}$ century Puritanism and piety were most fervent in the project of converting 'thelost souls' in Africa and giving the 'dark continent' the light of the gospel and Western civilisation (Ng'weshemi 2002:41; Akin in Motlhabi 1972:60-70; Zulu in Motlhabi 1972:87; Biko in Stubbs 1978:40-47,54-60). According to Ng'wesheni (2002:42): "As far as the missionaries were concerned, there was nothing positive in what Africans believed and practiced, and even their intellectual capacity was questioned".

Converts were detached from their communities and families and sent to mission stations. Their indigenous names were changed to Western names, the rites of passage were denied them and many other cultural and religious rituals were prohibited. These converts adopted an individualistic approach to life as Christianity itself was conceived of as a private, inner and personal affair between God and the individual.

This individual approach contributed to the destruction of the fabric of life, namely African traditions, family values and social life, which were based on communal religious and moral foundations (Ng'weshemi 2002:45).

Colonialism has also contributed to the dehumanisation of Africans. Whites regarded themselves as superior to the other races, with blacks at the bottom of the ladder. Colonial and missionary education was fashioned in a way which would 'scientifically' prove that whites were superior and Africans inferior, through the process known as lactification. This is a process by which the colonised peoples come to devalue their own beliefs and completely embrace without question the culture of the Western colonisers. Africans believed that to be fully human, they had to model themselves after the colonisers and reject everything that was African. This self-alienation led to self-hate.

Neo-colonisation in Africa is characterised by backwardness, poverty, disease and early death. Motlhabi (2008:103-120) discusses in depth the situation of post-colonial Africa's plight as a result of foreign interference and $\mathrm{Ng}^{\prime}$ weshemi (2002:58) hits the nail on the head when he states:

Neo-colonialism entails the existence of considerable foreign direction over a nominally independent nation. It is a situation in which a country's economic affairs and economic policy are influenced by another country or by foreign business interest.

\section{Reclaiming the Past}

After complaining about the loss or distortion of botho/ubuntu, is it possible to salvage and retrieve whatever remains of it? Any attempt at trying to "reclaim the African story" must consider a number of challenges.

a) We obviously cannot return to a pre-historical, pre-literate, pre-industrial and pretechnological understanding of botho/ubuntu. We certainly cannot go back to the cultures of Maat and Leopard's Kopje. In fact, Mazrui (2009:33-59) regards the meeting of "Africanism, Islam and the West" as a good thing, since the process did enrich Africa's wisdom. There are definitely certain basic tenets of botho/ubuntu that can be adopted for 
our own times in Africa in conjunction with the inherited cultures and religions. The human solidarity which is so integral to African cultures, for example, should be rekindled. The world has become so globalised that we as the human race have become truly one family. Therefore we can still be compassionate, empathetic, loving, etc. On the macro level, political leaders such as Julius Nyerere, Kenneth Kaunda and Jomo Kenyata have experimented politically, adopting some of the basic tenets of botho/ubuntu for their programmes and propounding ideas that were based on an African understanding of the family as a building block. Julius Nyerere's Ujamaa, for example, was based on the concept of family as a basis for a successful nation. It has to do with "community development and community upliftment" (Mcunu 2004:38). Ujamaa wanted to recapture and "spread the values of human dignity, equality, solidarity and human rights that traditionally existed in the family" (Ng'weshemi 2002:73) and religion was the cornerstone. Ujamaa is an ethic based on ubuntu. Kenneth Kaunda's 'African Humanism' is a humanist communitarian ethic that "exists in an African traditional society where community needs take precedence over individual self-gratification" (Murove in Nicholson 2008:105).

Communal ownership of property, egalitarianism, generosity, respect for human dignity, the centrality of the human being and lack of social classes are the main characteristics of the traditional society which is the basis of Zambian humanism (Ng'weshemi 2002:79).

Jomo Kenyata's Harambee means to pull together, to work together as a family or community. It demonstrates togetherness, which is one of the cornerstones of any successful family.

When people pool all their talents for a common cause, such as poverty alleviation, they are able to promote the well-being of everybody more than when each one is concerned with his/her own gain (Murove in Nicholson 2008:106).

Above all, African nations should craft their respective constitutions in a way that enshrines botho/ubuntu principles, with an ethic of communalism underpinning them.

b) As far as religion is concerned, it needs to be noted that, unlike during the past 2000 years, Africa is no longer a home to African religions only. Africa has become host to other religions such as Christianity, Buddhism, Islam and Hinduism. Interreligious relations should be adopted as a way forward in harnessing the good values and principles that could enrich and enhance botho/ubuntu on the continent. Obviously each religion should work out for itself what it could bring to the table. Christians on the continent, for example, have embarked on a theology that would be relevant for Africa since the start of independence from colonial masters in the mid-1950s.

Ng'weshemi(2002:82) states that:

African theology comes out of a search for freedom from the domination and imperialism of Western theology, which not only has been dumb on the African's experiential reality, but also has perpetuated the disorientation and oppression of African people, and the expansionist agenda and attitude of the West.

African theology is a theological reflection on the relationship of theology and culture on the continent, on the one hand, and social, economic and political realities, on the other. Ng'weshemi(2002:86) is convinced that: 
Recovering and affirming positive values of African culture and incorporating them into Christianity constitute an essential aspect of the process of liberation. In the final analysis, what inculturation seeks to achieve is to liberate Africans psychologically and internally, enabling them to rediscover themselves as people who have their own self-image and cultural identity.

c. As Africans begin seriously forging a culture based on the principles of botho/ubuntu for post-independence Africa, it must be acknowledged that not everything in African culture was very good and that not everything that was received from Western culture was very bad. In fact, Shutte (2001:10) believes that the two cultures could be taken into consideration when forging for a kind of botho/ubuntu that Africans can draw on nowadays. He says, "[t]he European idea is the idea of freedom, that individuals have a power of free choice. The African idea is the idea of community, that persons depend on other persons to be a person". For him individualism and communalism are not mutually exclusive, for the former is the glory of European culture and the latter the soul of Africa. But they have one thing in common: they deal with human beings and human nature.

A globalised world has made it possible to facilitate the mutual influence that cultures and religions have on one another. Cultures are not static and through interreligious relations even religions have begun to recognise that they all originate from one Source, whatever the name they give it. Therefore through processes such as adaptation, accommodation and even assimilation religions can contribute to crafting a culture of botho/ubuntu that can make Africa a continent of milk and honey. Diversity in the religious and secular spheres needs to be managed properly so that it becomes an asset rather than a liability. We should therefore resist the temptation of divinising African culture and religion, whilst demonising Western culture and religiosity.

\section{Conclusion}

The cornerstone of botho/ubuntu as a core value in African ethics is the community. Individuals cannot survive outside of their respective communities in as much as fish cannot survive outside of water. For the community to be strong and successful, individuals need to work together as a team. Postcolonial Africans have a huge responsibility of embedding themselves anew in a way of life deriving from the values of botho/ubuntu - if Africa as a continent is to be saved. Families are to be strengthened as building blocks of communities and strengthened communities would in turn become sound building blocks for a prosperous, caring and sharing continent. Urbanisation and industrialisation have uprooted people from their close-knit traditional village relationships. They have, for example, abandoned their communal way of life in favour of the individualised way of life in order to survive in towns and cities. As a result, the stronger do not only survive but prosper, while the weaker get pushed to the margins of wealth and riches, so much so that it is common these days to find whole families sleeping under bridges or on pavements. African governments should have the political will to abandon undemocratic ways and means of conducting their administration. Human rights should be respected as should the rule of law. The African Union must help foster these values and principles, while at the same time keeping external international forces in check.

Our humanness can only be enhanced in the context of a community with other humans and by extension with the whole of creation. When the West met Africa, colonists and 
missionaries thought that Africans were worshipping ancestors and nature. The fact of the matter was that Africans venerated ancestors as mediators between themselves and God and held in awe what God had created. They were well aware that their livelihood was inextricably linked to God's creation and therefore their philosophy of botho/ubuntu embraced also it. For example, some places such as lakes, rivers, mountains and forests would be declared sacred in order to guard them against destruction. There would be a myriad of taboos and rituals to make sure that there was harmony and balance in nature. In that way, the flora and the fauna in those places would be preserved for posterity. The idea of totems was also aimed at preserving nature. People would not hunt buffaloes indiscriminately if their totem was a buffalo. But Africans in general would not hoard plants and animals as the West did. An African or Asian would take out of nature only what they needed, and not what they wanted. Africa is a melting pot of cultures - it is African, Western, and Asian. It is also a melting pot of religious traditions, such as African, Christian, Islam and Hindu. Each of these religious traditions and cultures have very rich ingredients of botho/ubuntu that could be harnessed to make Africa a continent in which people can live more humanely with one another. In this age of globalisation, the respect and awe that Africans and Asians exhibit towards creation should be harnessed to avoid the pollution of the environment, depletion of natural resources such as the fauna and flora, as well as minerals under the soil. One would even go so far as to say that in order to implement the slogan 'going green', botho/ubuntu is the only organising principle that should be adopted.

\section{BIBLIOGRAPHY}

Akin, JO 1972. An African Expression of Christianity. In Essays on Black Theology edited by M Motlhabi 60-70. Johannesburg: University Christian Movement.

Berger, PL \& Berger, B 1976. Sociology: A Biographical Approach. Harmonsworth: Penguin Books.

Biko, S 1978. Some African Cultural Concepts. In I Write What I like edited by A Stubbs 40-47. London: The Bowerdean Press.

Biko, S 1978. The Church As Seen by a Young Layman. In I Write What I Like edited by A Stubbs 54-60. London: The Bowerdean Press.

Broodryk, J 2008. Understanding South Africa: the Ubuntu way of Living. Pretoria: Ubuntu School of Philosophy.

Bujo, B 2003. Foundations of an African Ethic: Beyond the Universal Claims of Western Morality. Kenya: Pauline's Publications Africa.

Chitando, E 2008. Religious Ethics, HIV and AIDS and Masculinities in Southern Africa. In Persons in Community: African Ethics in a Global Culture edited by R Nicholson 45-63. Pietermaritzburg: University of KZN Press.

Mafunisa, JM 2008. Ethics, African Societal Values and the Workplace. In Persons in Community: African Ethics in a Global Culture edited by R Nicholson 111-124 Pietermaritzburg: University of KZN Press.

Magesa, L 2002. African Religion: The Moral Traditions of Abundant Life. Maryknoll, New York: Orbis Books. 
Mazrui, AA 2009. Africa's Wisdom has Two Parents and One Guardian. In African Ethics edited by MF Murove 36-59. Pietermaritzburg: University of KwaZulu-Natal

Mbiti, JS 1991. Introduction to African Religion. Kenya: East African Educational Publishers Ltd.

Mbiti, JS 1970. Concepts of God in Africa. London: SPCK.

Mcunu, TN 2004. The Dignity of the Human Person: A Contribution of the Theology of Ubuntu to Theological Anthropology. Unpublished Master of Theology Dissertation, University of South Africa, Pretoria.

Mkhize, N 2008 Ubuntu and Harmony: An African Approach to Morality and Ethics. In Persons in Community: African Ethics in a Global Culture edited by R Nicholson 3544 Pietermaritzburg: University of KZN Press.

Mol, H 1976. Identity and the Sacred. Oxford: Basil Blackwell.

Murove, MF 2008. On African Ethics and the Appropriation of Western Capitalism: Cultural and Moral Constraints to the Evolution of Capitalism in the Post-Colonial Africa. In Persons in Community: African Ethics in a Global Culture edited by R Nicholson 85-110. Pietermaritzburg: University of KZN Press.

Motlhabi, M 2008. African Theology/Black Theology in South Africa: Looking Back, Moving On Pretoria: UNISA Press.

Ng'weshemi, AM 2002. Rediscovering the Human: The Quest for a Christo-Theological Anthropology in Africa. New York: Peter Lang Publishing Inc.

Setiloane, GM 1989. African Theology: An Introduction. Johannesburg: Skotaville.

Shutte, A 2001. Ubuntu: An Ethic for a New South Africa. Pietermaritzburg: Cluster Publications.

Zulu, LB 1972. Nineteenth Century Missionaries: Their Significance for Black South Africa. In Essays on Black Theology edited by M Motlhabi 85-90. Johannesburg: UCM. 